\title{
Study of soil erosion risks using RUSLE Model and remote sensing: case of the Bouregreg watershed (Morocco)
}

\author{
Fatima Hara $^{1}$, Mohammed Achab ${ }^{1}$, Anas Emran ${ }^{1}$, and Gil Mahe ${ }^{2}$ \\ ${ }^{1}$ Geo-Biodiversity and Natural Patrimony Laboratory(GEOBIO,)Scientific Institute, Geophysics, Natural \\ Patrimony and Green Chemistry Research Centre(GEOPAC), Mohammed V \\ University in Rabat, 10106 Rabat, Morocco \\ ${ }^{2}$ HydroSciences Montpellier/IRD, 34090 Montpellier, France \\ Correspondence: Fatima Hara (fatimahara1@gmail.com) \\ Published: 16 September 2020
}

\begin{abstract}
The Bouregreg watershed is located to the north-western center of Morocco, characterized by a semi-arid climate. It covers a total area of approximately $10000 \mathrm{~km}^{2}$. This basin is a very sensitive area to water erosion. This causes the degradation of its vegetation cover and its land. The most sensitive and poorly protected soils erode much more easily and lose their fertility.The objective of this work is to quantify soil losses by water erosion in the Bouregreg watershed using the Revised Universal Loss Equation (RUSLE) and Geographic Information Systems. The average annual rate of soil erosion in the Bouregreg watrershed are estimated at $20 \mathrm{tha}^{-1} \mathrm{yr}^{-1}$. The spatial distribution map of soil erosion show that $71 \%$ of the total area has low risk of soil erosion $\left(<3 \mathrm{tha}^{-1} \mathrm{yr}^{-1}\right)$, while $28 \%$ of the study area shows moderate to high risk of erosion (20$60 \mathrm{tha}^{-1} \mathrm{yr}^{-1}$ ). Areas of very high risk of erosion are also present in some sectors of the watershed covering $1 \%$ of the total surface.
\end{abstract}

\section{Introduction}

Soil erosion has been recognized as the major cause of land degradation worldwide and becomes a serious environmental and economic problem when accentuated by human activities (Del Mar López et al., 1998). On the other hand, water erosion is the main factor of the deterioration of the soil resource (Wachal, 2007). The soil loss phenomena have accelerated around the world (De Graaf, 1996). Water erosion risk assessment involves mapping and analyzing many factors involved in the erosive process: rainfall erosivity, soil erodibility, slope length and vegetal cover factors (Wischmeier and Smith, 1978).

Morocco is one of the Mediterranean countries that have always suffered from land degradation and mismanagement. Soil erosion characterizes the majority of Morocco's reliefs. FAO study (1990) revealed that the situation continues to deteriorate and becomes more and more critical, and evaluate that almost $40 \%$ of land in Morocco are affected by erosion.
The Bouregreg watershed (approximately $10000 \mathrm{~km}^{2}$ ) topic of this study is located between latitudes 32.8 and $34^{\circ} \mathrm{N}$ and longitudes 5.4 and $6.8^{\circ} \mathrm{W}$. This watershed constitutes a very sensitive area to degradation of soil and vegetation by water erosion. the sediments resulting from this degradation contribute to the siltation of the SMBA dam, located to the north of the watershed and producing about $31 \%$ of Morocco's drinking water specially those of two large Moroccan cities, Rabat and Casablanca.

The climate of Bouregreg watershed is Mediterranean. It ranks globally in the semi-arid bioclimatic stage. The average rainfall varies from $450 \mathrm{~mm} \mathrm{yr}^{-1}$ in Rabat and $750 \mathrm{~mm} \mathrm{yr}^{-1}$ in high altitude areas (Oulmès). The average temperatures are near Atlantic and in mountain areas. They vary between 15 and $25^{\circ} \mathrm{C}$. They are strongly influenced by warm currents in dry periods. The average high temperatures during (JulyAugust) alternate between 30 and $34^{\circ} \mathrm{C}$ in the Bouregreg and between 26 and $28^{\circ} \mathrm{C}$ in the coastal zone (PDAIRE, 2011). 


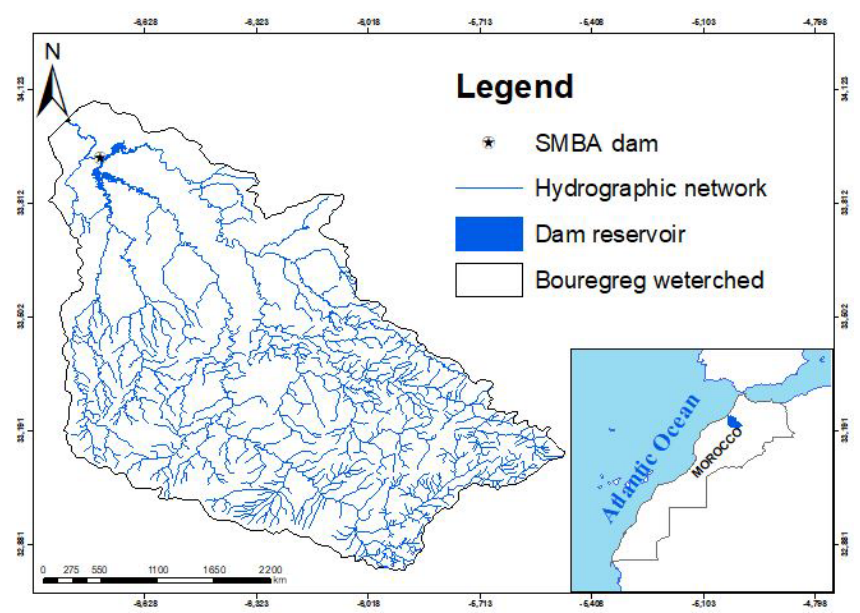

Figure 1. Location of the Bouregreg Watershed.

The proposed study attempts by using the Revised Universal Loss Equation (RUSLE) and Geographic Information Systems to quantify soil losses rate and the effect of vegetation and land cover/use changes on soil erosion in this watershed.

\section{Methodology}

The Quantification of soil losses rate in the Bouregreg watershed was performed by the application of the Revised Universal Soil Loss Equation (Wischmeier and Smith, 1978).

The USLE method of Wischmeier and Smith (1978) represented an important step in the history of water erosion modeling. It is the most used model for a global estimate of losses due to the process of surface erosion, with her revised RUSLE model, grace to the ease of its implementation and its compatibility with geographic information systems (Millward and Mersey, 1999). The RUSLE model has been recognized as the most widely used model for the prediction and spatial distribution of annual average soil loss by integrating different erosion factors (Renard et al., 1997). The equation is expressed by the relation:

$A=R \cdot K \cdot L S \cdot C \cdot P$

where $A$ is the average annual soil loss $\left(\mathrm{tha}^{-1} \mathrm{yr}^{-1}\right), \quad R$ is The Rainfall and Runoff Factor $\left(\mathrm{MJ} \mathrm{mm}^{-1} \mathrm{ha}^{-1} \mathrm{~h}^{-1} \mathrm{yr}^{-1}\right), \quad K$ is the Soil Erodibility Factor $\left(\mathrm{tha}^{-1} \mathrm{~h}^{-1} \mathrm{ha}^{-1} \mathrm{MJ}^{-1} \mathrm{~mm}^{-1}\right), \quad L S$ is the Slope Factor, $C$ is the Crop/Vegetation and Management Factor, $P$ is the Support Practice Factor.

\section{Results and discussion}

\subsection{Climate aggressiveness factor $R$}

The rainfall erosivity is an indicator of precipitation aggression. This factor was estimated by the Arnoldus formula

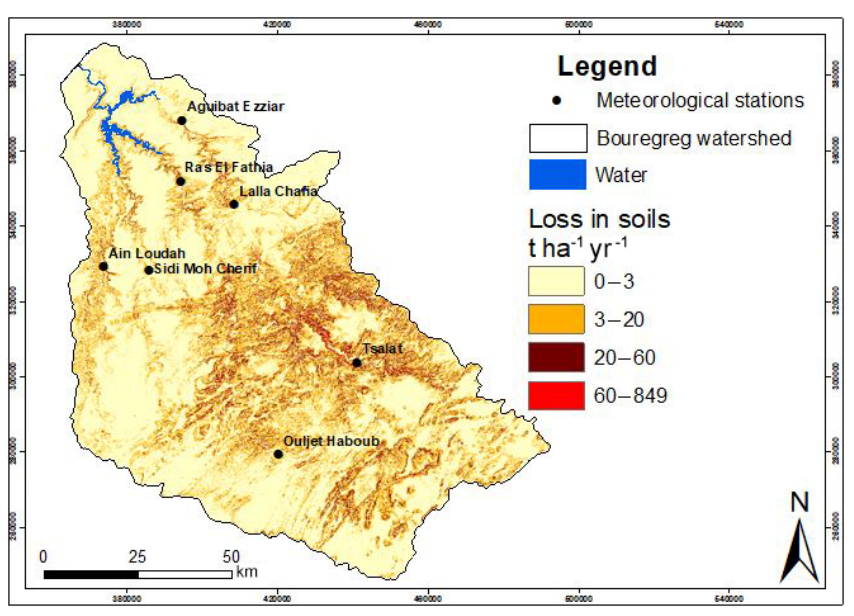

Figure 2. Spatial distribution map of soil losses in the Bouregreg watershed.

Table 1. Distribution of soil losses in the Bouregreg watershed.

\begin{tabular}{lrrl}
\hline $\begin{array}{l}\text { Soil loss } \\
\left(\mathrm{tha}^{-1} \mathrm{yr}^{-1}\right)\end{array}$ & $\begin{array}{r}\text { Area } \\
(\mathrm{ha})(\%)\end{array}$ & Area & Erosion risk \\
\hline $0-3$ & 705300 & 71 & Low \\
$3-20$ & 213900 & 22 & Moderate \\
$20-60$ & 61000 & 6 & High \\
$60-849$ & 6000 & 1 & Very high \\
\hline Total & 989800 & 100 & \\
\hline
\end{tabular}

(Arnoldus, 1977) to eight stations in the Bouregreg watershed (Fig. 2) on 36-year period (1977-2013). The formula based on monthly mean precipitation $(p i)$ and average annual rainfall $(p)$. The interpolation values of these stations gave a distribution map of this factor ranging from 29.53 to 57.87. The map shows an increase in values from the northeast of the basin to the southwest, where there are the highest altitudes.

\subsection{The erodibility factor $K$}

The erodibility factor $(K)$ is a function of soil texture, structure, organic matter content and permeability. In our case, due to the lack of this type of data, we opted to use FAO Digital SoilMap data from the World (http://www.fao.org/land-water/land/land-governance/ land-resources-planning-toolbox/category/details/en/c/ 1026564/, last access: 12 August 2020). The results obtained show that the $K$ factor varies from 0.0139 to 0.0214 .

\subsection{The topographic factor $L S$}

The topographic factor $(L S)$ was calculated from the inclination of the slopes and their length by the formula of Wis- 
chmeier and Smith (1978):

$L S=(L / 22.13) m(0.065+0.045 \cdot S+0.065 \cdot S 2)$

where $L$ is the slope length in $m, S$ is the inclination of the slope in $\%, m$ is a parameter such that $m=0.5$ if the slope is $>5 \%, m=0.4$ if the slope is $3.5 \%$ to $4.5 \%, m=0.3$ if the slope is $1 \%$ to $3 \%$ and $m=0.2$ if the slope is $<1 \%$.

$L S$ factor values range from 0 to 1440 . The length and degree of inclination of the slope are decisive in the process of erosion. $L S$ values are very high in the southwestern part of the Bouregreg watershed.

\subsection{The factor of vegetation covers $C$}

The evaluation of this factor in Bouregreg watershed is made by adapting the equation of Van Der Knijff (2000).

$C=\exp [-\alpha \times \mathrm{NDVI} /(\beta-\mathrm{NDVI})]$

where $\alpha, \beta$ : parameters determining the shape of the NDVI$C$ curve with $\alpha=2$ and $\beta=1$ and NDVI is normalized difference vegetation index.

The NDVI was evaluated by operating a satellite image Landsat 8 dated 2018. The results obtained show that the $C$ factor varies from 0.054 to 1 .

\subsection{The factor of erosion control practices $P$}

In the case of our study, and in the absence of anti-erosion practices in the study area, the $P$ factor is assigned a value of 1 .

\subsection{Evaluation of soil losses}

Soil losses result from the combination of the RUSLE model factors, climatic aggressivity $R$, soil erodibility $K$, topographic factor $L S$, vegetation cover $C$ and anti-erosion practices $P$. The combination of the maps of these The main factors in a GIS environment resulted in the map of soil losses in the watershed (Fig. 2).

Average soil losses in the Bouregreg watershed are estimated at $20 \mathrm{tha}^{-1} \mathrm{yr}^{-1}$. Soil losses in the Bouregreg watershed have been grouped into 4 classes of values (Fig. 2 and Table 1).

\section{Conclusions}

The study of risk of erosion in the Bouregreg watershed was performed using the Revised Universal Equation of Sol Losses (RUSLE). The different factors of the model have been estimated (Eq. 1) and spatialised in a GIS environment. The combination of these different factors made possible the elaboration of the erosion risk map. The results obtained show that the study area is subject to climatic aggressiveness and show a moderate vulnerability of soils to water erosion. however, the risk of soil erosion is high in some sectors of the watershed.

Data availability. The availability and the nature of the numerical data (geological, climatological and pedological, land use) used in the calculation of the erosion and sedimentation processes in the study basin, is well prepared for the use of the universal equations of revised soil loss (RUSLE). These data have been integrated, listed and digitally processed in a Geographic Information System. Other image processing software were also used (QGis, Erdas, Envi) for the delimitation of the watershed and the extraction of their geometric properties (surface area, average altitude, etc.). For this we based ourselves on a digital terrain model (DEM) at $30 \mathrm{~m}$ resolution, which also served us as a basis for the extraction of the hydrographic network and the digital calculation of the different thematic maps of the basin.

Author contributions. FH write the paper, AM conducted review and editing, AE and GM project administration and resources.

Competing interests. The authors declare that they have no conflict of interest.

Special issue statement. This article is part of the special issue "Hydrological processes and water security in a changing world". It is a result of the 8th Global FRIEND-Water Conference: Hydrological Processes and Water Security in a Changing World, Beijing, China, 6-9 November 2018.

Acknowledgements. The authors would like to thank the Bouregreg and Chaouia watershed hydraulic agency for collaboration. They would also like to thank all of the reviewers for providing valuable input to earlier versions of this manuscript.

\section{References}

Arnoldus, H. M. J.: Methodologye used to determine the maximum potentialaverage annual soil loss due to shett and rill erosion in Morocco, FAO Soil Bull., 34, 39-51, 1977.

Del Mar López, T., Mitchel Aide, T., and Scatena, F. N.: The effect of land use on soil erosion in the Guadiana watershed in Puerto Rico, Carib. J. Sci., 34, 298-307, 1998.

De Graaf, J. (Ed.): Price of soil erosion: an economic evaluation of soil conservation and watershed development, Agricultural University Wageningen, 300 pp., 1996.

Millward, A. A. and Mersey, J. E.: Adapting the RUSLE to model soil erosion potential in a mountainous tropical watershed, CATENA, 38, 109-129, 1999.

PDAIRE: Project Study Plan Director Renovation An Integrated Water Resources hydraulic basin Bouregreg and Chaouia, available at: http://81.192.102.15/index.php/pdairleft (last access: 9 August 2020), 2011. 
Renard, K. G., Foster, G. R., Weesies, G. A., McCool, D. K., and Yoder, D. C.: Predicting soil erosion by water - a guide to conservation planning with the Revised Universal Soil Loss Equation (RUSLE). United States Department of Agriculture, Agricultural Research Service (USDA-ARS) Handbook No. 703, 1997.

Van der Knijff, J. M., Jones, R. J. A., and Montanarella, L.: Soil Erosion Risk Assessment in Europe, EUR 19044 EN, 34 pp., 2000.
Wachal, D. J.: Integrating GIS and erosion modeling - A tool for watershed management, ESRI international user conference, $\mathrm{Pa}$ per No. UC1038, 11 pp., 2007.

Wischmeier, V. H. and Smith, D. D.: Predicting rainfdl erosion losses - a guide to conservation planning, United States Department of Agriculture in cooperation with Purdue Agricultural Experiment Station. United States Department of Agriculture, Washington, Agriculture Handbook No. 282, 1978. 